\title{
Caspases are the main executioners of Fas-mediated apoptosis, irrespective of the ceramide signalling pathway
}

\author{
Susana Gamen ${ }^{1}$, Alberto Anel ${ }^{1}$, Andrés Piñeiro ${ }^{1}$ \\ and Javier Naval ${ }^{1,2}$ \\ ${ }^{1}$ Departamento de Bioquímica y Biología Molecular y Celular, Facultad de \\ Ciencias, Universidad de Zaragoza, 50009 Zaragoza, Spain \\ 2 corresponding author: Javier Naval; Departmento de Bioquímica y Biología \\ Molecular; Facultad de Ciencias Universidad de Zaragoza, 50009 Zaragoza, \\ Spain. Fax: 34-976 762 123; email: jnaval@posta.unizar.es
}

Received 8.8.97; revised 12.9.97; accepted 10.10.97

Edited by M Piacentini

\begin{abstract}
Tumor necrosis factor $\alpha$ (TNF) or cytotoxic anti-Fas antibodies lead to the activation of apoptotic proteases (caspases) and to sphingomyelinase-mediated ceramide generation. Caspases and ceramide are both known to induce apoptosis on its own, but their relative contribution to Fas- and TNF-induced cell death is not well established. We report here that rapid apoptosis induced by TNF in U937 cells or anti-Fas in Jurkat cells, in the presence of cycloheximide, induced only a very low increase $(<20 \%)$ in the cell ceramide content. Neither treatment with inhibitors of sphingomyelinases nor incubation of cells with fumonisin $B_{1}$, which inhibits de novo ceramide synthesis, prevented TNF and Fas-mediated apoptosis. Increasing or depleting the cell ceramide content by prolonged culture in the presence of monensin or fumonisin B1, respectively, did not prevent TNF and Fas-mediated apoptosis. Treatment of cells with sphingomyelinase inhibitors did not affect to the activation of CPP32 (caspase-3) induced by TNF or anti-Fas antibodies. Chromatin condensation and fragmentation in cells treated with anti-Fas or TNF was abrogated by peptide inhibitors of caspases, which also inhibited Fas-, but not TNF-induced cell death. These results indicate that while ceramide does not seem to act as a critical mediator of TNF and Fas-induced apoptosis, it is generated as a consequence of CPP32 activation and could contribute to the spread of the intracellular death signal.
\end{abstract}

Keywords: Fas; TNF; ceramide; sphingomyelinase; CPP32; apoptosis

Abbreviations: TNF, Tumour necrosis factor- $\alpha$; TNFR, TNF- $\alpha$ receptor; FasL, Fas ligand; $\mathrm{FB}_{1}$, Fumonisin $\mathrm{B}_{1}$; MTT, 3-[4,5dimethylthiazol]-2,5-diphenyl-tetrazolium bromide; Ac-DEVD$\mathrm{CHO}, \mathrm{N}$-acetyl-Asp-Glu-Val-Asp aldehyde; Z-VAD-fmk, benzyloxycarbonyl-Val-Ala-Asp-fluoromethylketone; Boc-D-fmk, tbutyloxy-carbonyl-Asp-fluoromethylketone

\section{Introduction}

The Fas molecule and the receptor for tumour necrosis factor $\alpha$ (TNF) belong to a family of surface molecules which possess the so-called death domain, which upon occupancy by their corresponding physiological ligands (FasL and TNF, respectively) trigger apoptosis (Henkart, 1996). The transduction of the apoptotic signal generated by these occupied receptors is not fully known but involves the recruitment and sequential activation of cytosolic cysteine proteases with Asp specificity (ICE/CED3-like proteases or caspases) (Chinnayian et al, 1996) and the activation of sphingomyelinases (Kolesnick and Golde, 1994; Tepper et al, 1995; Gamen et al, 1996). The active caspases and the product of sphingomyelinase activity, ceramide, can both induce apoptosis in sensitive cells when transfected or exogenously added, respectively (Tewari et al, 1995; Gamen et al, 1996; Henkart, 1996). Active proteases of the CPP32 subfamily of caspases cause the hydrolysis of a number of cell proteins such as ply(ADP-ribose) polymerase (PARP), the $70 \mathrm{kDa}$ protein component of the U1-ribonucleoprotein (U1-70 kDa), DNA-dependent protein-kinase (DNA$\mathrm{PK}_{\mathrm{cs}}$ ) and lamin A (Casciola-Rosen et al, 1996; Greidinger et al, 1996). On the other hand, it has been described that ceramide activates a protein kinase, recently identified as cRaf (Huwiler et al, 1996), and a protein phosphatase (Dobrowsky et al, 1993). Ceramide has been also proven to be a key mediator of irradiation-induced apoptosis (Santana et al, 1996). The cleavage of the above mentioned proteins, and probably others, critical for cell homeostasis, as well as the activation of ceramide-dependent kinases and phosphatases acting on nuclear targets (Huwiler et al, 1996) may thus constitute the executive phase of apoptotic cell death.

However, the relative contribution of ceramide to the apoptotic processes triggered by TNF and FasL (or cytotoxic anti-Fas antibodies) is presently ill-defined. We have recently demonstrated that Fas-induced activation of CPP32-like proteases is a pre-requisite for ceramide generation and apoptosis in human cells (Gamen et al, 1996). In addition, in the short-time $(4 \mathrm{~h})$ Fas-mediated lysis caused by FasLexpressing effector cells, no rise in the levels of cellular ceramide could be noticed (Anel et al, 1997). This prompted us to determine if ceramide generation after Fas or TNFreceptor (TNFR) ligation is an essential event in the intracellular pathway of cell death or a secondary mechanism for amplification or diversification of the death signal. Our present results support the latter possibility.

\section{Results}

Effect of sphingomyelinase inhibitors on TNF and Fas cytotoxicity

U937 and Jurkat cells possess both neutral and acidic sphingomyelinases that become activated upon TNF and 
Fas stimulation (Cifone et al, 1993; Wiegmann et al, 1994; Boucher et al, 1995; Gamen et al, 1996). To evaluate the contribution to apoptosis of sphingomyelinase-generated ceramide, as a first approach, U937 and Jurkat cells were treated with cytotoxic anti-Fas antibodies or TNF in the presence or absence of inhibitors of neutral (EDTA) (Wiegmann et al, 1994; Tepper et al, 1995) and acidic (ammonium chloride, chloroquine and monensin) (Wiegmann et al, 1994; Andrieu et al, 1996) sphingomyelinases. Since incubations with these compounds (at the concentrations reported to be inhibitory) for the times required for physiological cell lysis $(8-12 \mathrm{~h}$ for anti-Fas, $24-48 \mathrm{~h}$ for TNF), produced a high toxicity, tests were performed in the presence of cycloheximide to accelerate the onset of cell death (Schulze-Osthoff et al, 1994) (Figure 1). Under these conditions, the inhibitors did not induce any toxicity per se. Only monensin treatment had a slight protective effect on Fas-induced apoptosis in U937 cells at $3 \mathrm{~h}$, but this effect was not observed at longer incubation times (Figure 1b). The other sphingomyelinase inhibitors tested offered very low or no protection to Jurkat and U937 cells treated with anti-Fas or TNF at any time point tested (Figure 1).

\section{Effect of sphingomyelinase inhibitors on ceramide generation}

Cells treated for $3.5 \mathrm{~h}$ with anti-Fas antibodies or for $6 \mathrm{~h}$ with TNF, in the presence of cycloheximide, showed a slight increase (around $20 \%$ in both cases) in the ceramide to sphingomyelin ratio (Figure 2). Treatment of Jurkat and U937 cells with a combination of monensin and EDTA, in the absence of TNF and anti-Fas, caused a greater increase in the ceramide to sphingomyelin ratio (47 and $66 \%$, respectively). This fact was probably due to the intracellular accumulation of ceramide by monensin blockade of its transport to the plasma membrane (Kallen et al, 1993; Andrieu et al, 1996). This increase in the cell ceramide content was not associated, however, with any observable cytotoxicity during the experimental period, in spite of being greater than that induced by anti-Fas or TNF (Figure 2). Anti-Fas or TNF treatment caused a considerable cytotoxicity, comparable to that shown in Figure 1 , irrespective of the presence or absence of sphingomyelinase inhibitors. Treatment with anti-Fas or TNF, in the presence of monensin and EDTA produced only a modest increase (28 and $18 \%$, respectively) in the ceramide to sphingomyelin ratio. This increase was probably due to a residual activity of neutral sphingomyelinase, since monensin, at the concentrations used, efficiently inhibits acid sphingomyelinase activity in intact cells (Wiegmann et al, 1994; Boucher et al, 1995). EDTA was used to chelate extracellular $\mathrm{Mg}^{2+}$, in an attempt to block the activity of neutral sphingomyelinase, which is localised at the plasma membrane and externally oriented (Das et al, 1984). However, intracellular $\mathrm{Mg}^{2+}$, unlike calcium, does not exchange with extracellular $\mathrm{Mg}^{2+}$ (Murphy et al, 1989) and simultaneous incubation of cells with EDTA and an intracellular $\mathrm{Mg}^{2+}$-chelator elicited a great cytotoxicity (data not shown). As an alternative to estimate the possible contribution of the neutral sphingomyelinase activity to
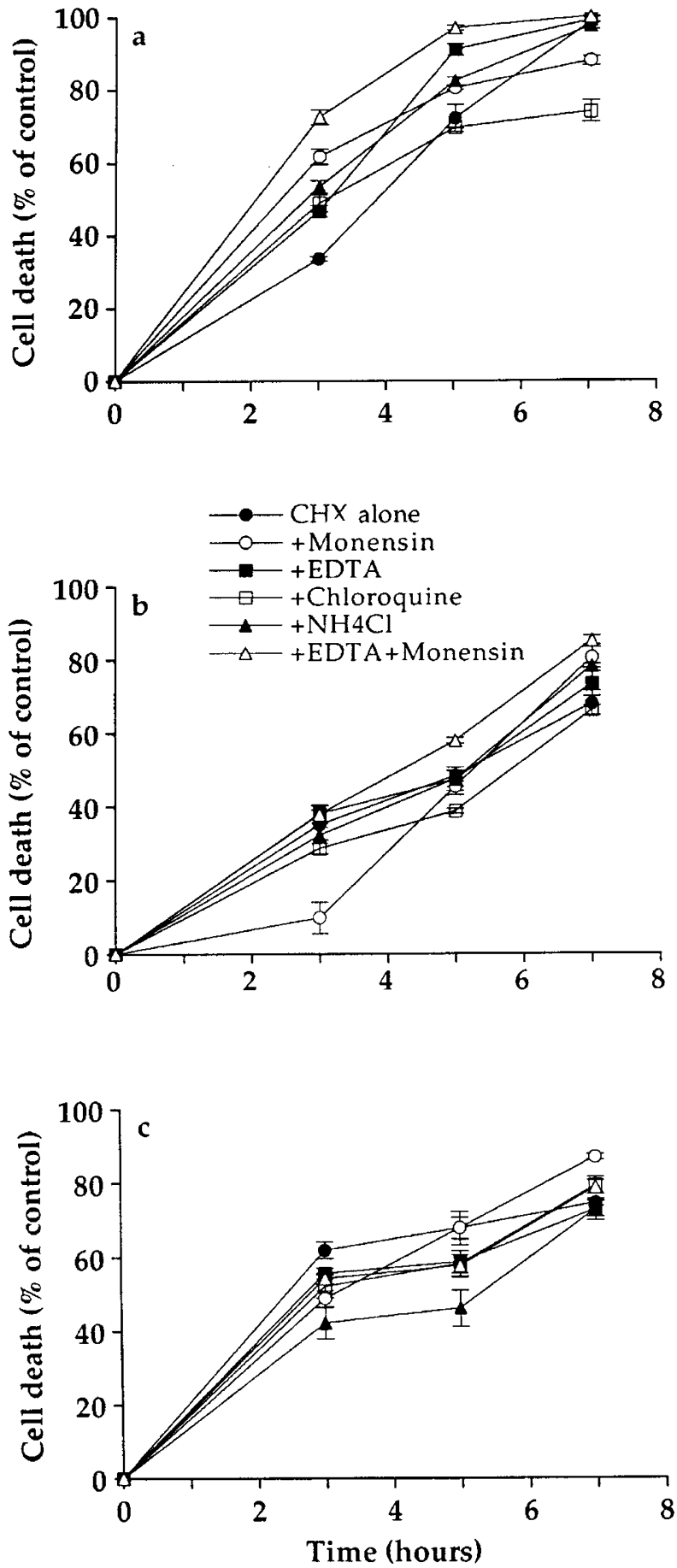

Figure 1 Sphingomyelinase inhibitors did not prevent Fas or TNF-induced apoptosis. Jurkat (a) and U937 (b, c) cells were pretreated for $30 \mathrm{~min}$ in complete medium containing $10 \mu \mathrm{g} / \mathrm{ml}$ cycloheximide and either $10 \mu \mathrm{g} / \mathrm{ml}$ monensin, $10 \mu \mathrm{M}$ chloroquine, $8 \mathrm{mM}$ ammonium chloride, $1 \mathrm{mM}$ EDTA or a combination of monensin and EDTA, as indicated. Then, anti-Fas $(100 \mathrm{ng} / \mathrm{ml})$ $(\mathbf{a}, \mathbf{b})$ or TNF $(300 \mathrm{U} / \mathrm{ml})(\mathbf{c})$ were added and cells incubated for the indicated times. Cultures containing the same amounts of inhibitors, without TNF or antiFas, were used as controls. Cell death was determined by the MTT-assay. Results are the mean values of determinations on four to five individual cultures. Vertical bars indicate S.D. 
apoptosis, cells were treated with bacterial sphingomyelinase $(0.4 \mathrm{U} / \mathrm{ml})$ for $16 \mathrm{~h}$, which virtually eliminates all the plasma membrane sphingomyelin (Hidari et al, 1996). This treatment did not induce apoptosis per se nor affected to anti-Fas and TNF-induced apoptosis (data not shown).

The possible contribution of the de novo synthesised ceramide to TNF and anti-Fas induced apoptosis in the presence of cycloheximide was tested by addition to culture media of $\mathrm{FB}_{1}$, a strong inhibitor of ceramide synthase (Hidari et al, 1996; Jaffrézou et al, 1996). $\mathrm{FB}_{1}$ did not reduce TNF and Fas cytotoxicity in any case (Figure 3).
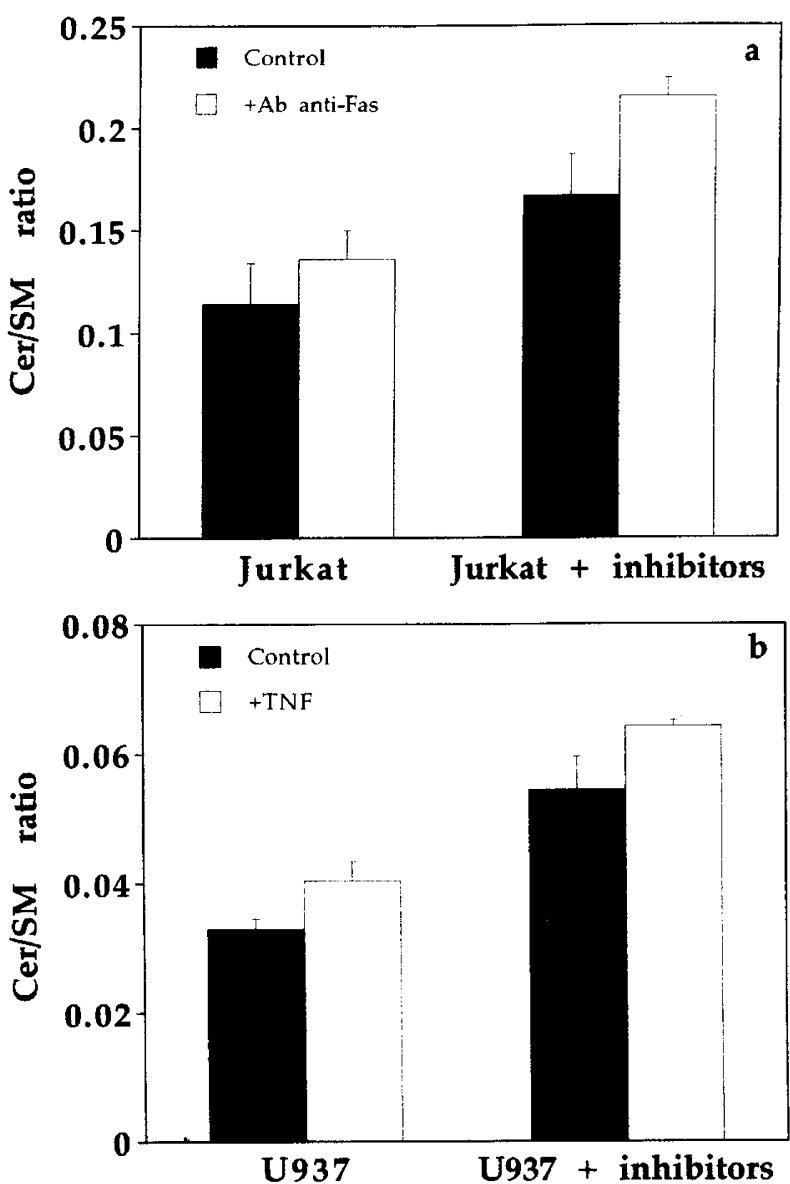

Figure 2 Effect of treatment with sphingomyelinase inhibitors and anti-Fas or TNF on the cell ceramide levels. Jurkat $\left(5 \times 10^{5} \mathrm{cells} / \mathrm{ml}\right)$ and $U 937$ $\left(3 \times 10^{5} \mathrm{cells} / \mathrm{ml}\right)$ cells, prelabelled for $48 \mathrm{~h}$ with $0.5 \mu \mathrm{Ciml}$ of $\left[1-{ }^{14} \mathrm{C}\right]$ palmitic acid, were incubated for $30 \mathrm{~min}$ in complete medium containing $10 \mu \mathrm{g} / \mathrm{ml}$ cycloheximide and a combination of sphingomyelinase inhibitors $(10 \mu \mathrm{g} / \mathrm{ml}$ monensin and $1 \mathrm{mM}$ EDTA). Then $100 \mathrm{ng} / \mathrm{ml}$ anti-Fas (a) or $300 \mathrm{U} / \mathrm{ml}$ TNF (b) were added and the cells incubated for 3.5 (Jurkat) or $6 \mathrm{~h}$ (U937). Cell death was determined in an aliquot of cell suspensions and cell lipids analyzed by TLC as indicated in Materials and Methods. Cultures containing the same amounts of inhibitors alone were used as controls. Results are expressed as the ratio of radioactivity in ceramide (Cer) to sphingomyelin (SM) fractions and correspond to one representative experiment. Data are the mean of three individual determinations. Vertical bars indicate S.D. Radioactivity recovered in ceramide and sphingomyelin fractions from control cells was around 1000 and 12000 c.p.m., respectively for Jurkat and 12000 and 42000 c.p.m., respectively for U937 cells

\section{Effect of chronic treatment with $\mathrm{FB}_{1}$ or monensin on ceramide content and TNF and Fas cytotoxicity}

As an approach to study the contribution of ceramide to TNF and Fas-mediated apoptosis in the absence of cycloheximide, cells were depleted of ceramide and sphingomyelin by prolonged culture in the presence of the ceramide synthase inhibitor $\mathrm{FB}_{1}$. Treatment with $\mathrm{FB}_{1}$ reduced the cell ceramide content to about a half and spingomyelin content to the 15 and $2 \%$ of that of untreated Jurkat and U937 cells, respectively (Figure 4). Anti-Fas induced approximately a twofold increase in ceramide content in control cells while this increase was marginal in $\mathrm{FB}_{1}$-treated cells. In spite of this, cell death induced by anti-Fas was similar in $\mathrm{FB}_{1}$-treated or untreated cells (Table 1). Unexpectedly, treatment of U937 with $\mathrm{FB}_{1}$ for $72 \mathrm{~h}$ significantly diminished the sensitivity to TNF (25 and $10 \%$ of cell death at $25 \mu \mathrm{M}$ and $50 \mu \mathrm{M}$ FB1, respectively, versus $50 \%$ in controls). Flow cytometric analysis with specific anti $55 \mathrm{kDa}$ TNFR and anti Fas antibodies revealed a reduction in the number of TNF receptors to about $60 \%$ of the value in control cells while no changes in Fas expression were observed (data not shown). Accordingly, the changes in ceramide and sphingomyelin levels in response to TNF triggering were not further evaluated.

Culture of U937 cells with monensin for $36 \mathrm{~h}$ caused a near tenfold increase in the cell ceramide content, irrespective of Fas or TNFR ligation (Figure 5). Incubation of U937 cells for $16 \mathrm{~h}$ with TNF, in monensin-treated or untreated cells, induced only minor changes in the cell ceramide content (Figure 5), while causing around a 30\% of cell death in both experimental conditions (Table 1). AntiFas induced a twofold increase in ceramide levels in untreated cells, while the increase was only of $12 \%$ in

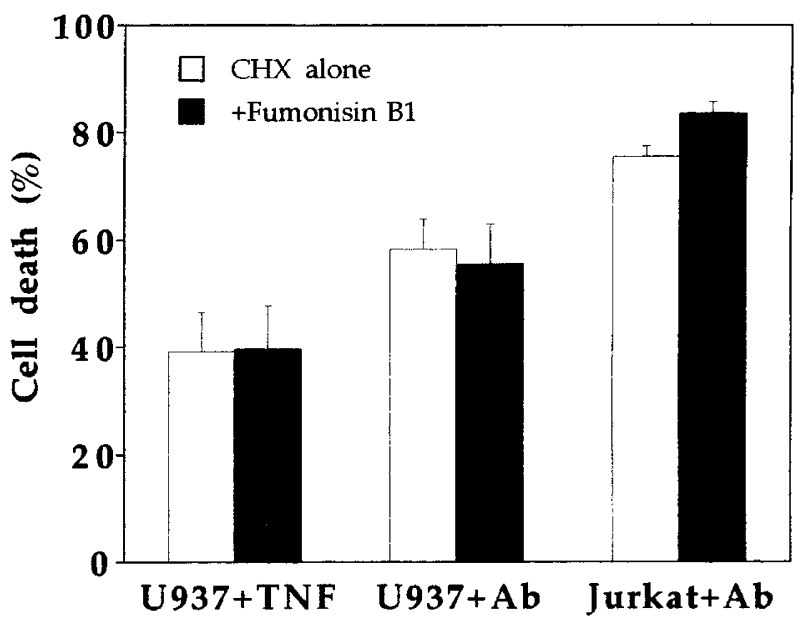

Figure 3 Inhibition of the de novo ceramide synthesis has no effect on Fas and TNF-mediated apoptosis. Jurkat $\left(5 \times 10^{5} \mathrm{cells} / \mathrm{ml}\right)$ and $U 937$ cells $\left(3 \times 10^{5}\right.$ cells $\left./ \mathrm{ml}\right)$ were preincubated for $30 \mathrm{~min}$ in complete medium containing $10 \mu \mathrm{g} / \mathrm{ml}$ cycloheximide and $25 \mu \mathrm{M}$ fumonisin $\mathrm{B}_{1}$ an inhibitor of ceramide synthase. Then cells were incubated, in the same media, with $300 \mathrm{U} / \mathrm{ml}$ TNF or $100 \mathrm{ng} / \mathrm{ml}$ anti-Fas for $6 \mathrm{~h}$ and cell death determined by the MTT-assay. Results are the mean values of determinations from four individual cultures. Vertical bars indicate S.D. 

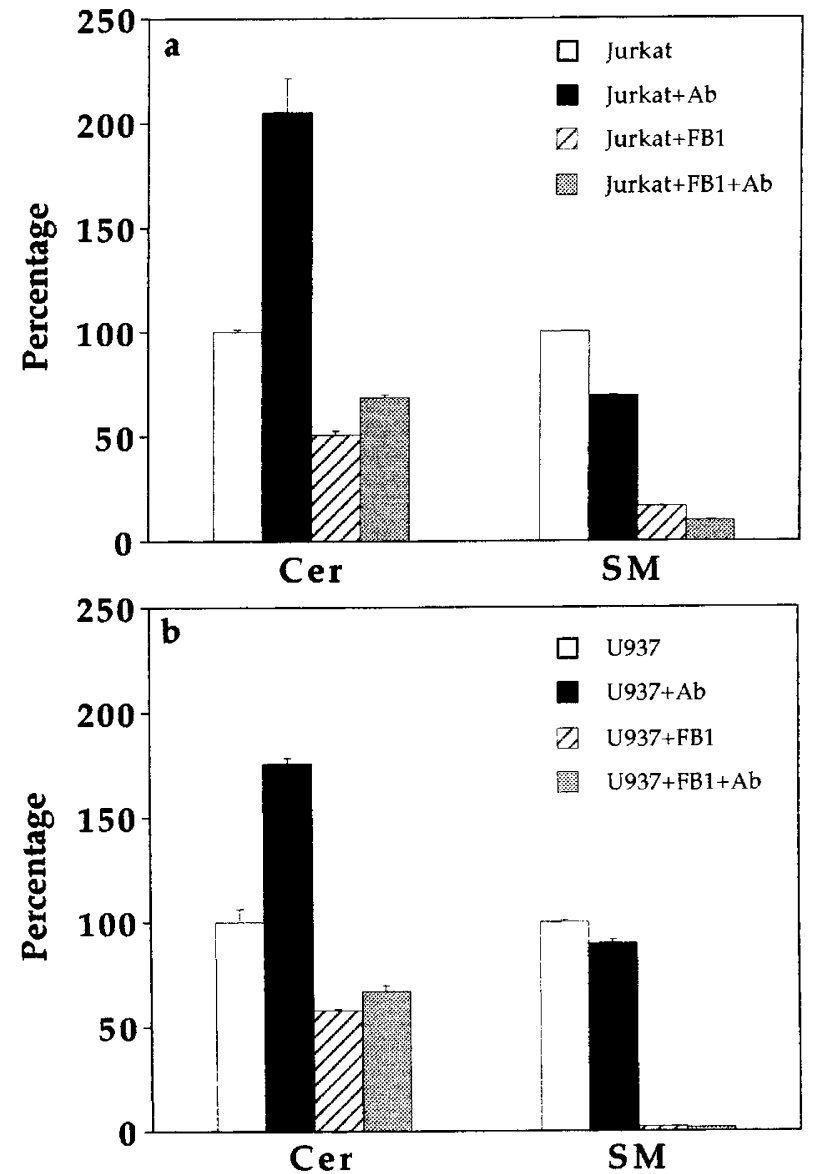

Figure 4 Chronic treatment with fumonisin $B_{1}$ greatly reduces the cell ceramide and sphingomyelin content. Jurkat (a) and U937 (b) cells $\left(3 \times 10^{5}\right)$ $\mathrm{ml}$ ) were pretreated with $50 \mu \mathrm{M}$ fumonisin $\mathrm{B}_{1}\left(\mathrm{FB}_{1}\right)$ for $24 \mathrm{~h}$. Then, $0.5 \mu \mathrm{Ci} / \mathrm{ml}$ of $\left[1-{ }^{14} \mathrm{C}\right]$ palmitic acid were added to $\mathrm{FB}_{1}$-containing medium and cells cultured for a further $48 \mathrm{~h}$. Cells were resuspended at $5 \times 10^{6}$ (Jurkat) or $3 \times 10^{6}$ (U937) cells $/ \mathrm{ml}$, in fresh medium containing $50 \mu \mathrm{M} \mathrm{FB}_{1}$ and $50 \mathrm{ng} / \mathrm{ml}$ anti-Fas. After $15 \mathrm{~h}$ of incubation, cell death was estimated in an aliquot of the cell suspensions and the cellular lipids analyzed by TLC. Radioactivity in the ceramide (Cer) and sphingomyelin (SM) fractions was determined by liquid scintillation counting (around $500-1000$ for Cer and $12000-23000$ c.p.m. for $\mathrm{SM}$, respectively in control cells). Results are expressed as percentage of radioactivity in untreated controls and are the mean of individual determinations on three separate cultures. Vertical bars indicate S.D.

Table 1 Anti-Fas and TNF-induced apoptosis in cells cultured with monensin or fumonisin $\mathrm{B}_{1}$

\begin{tabular}{lcc}
\hline & \multicolumn{2}{c}{ Cell death (\%) } \\
Treatment & U937 & Jurkat \\
\hline +anti-Fas & 58.3 & 72.8 \\
+anti-Fas+monensin & 58.6 & $\mathrm{ND}$ \\
+anti-Fas+FB & 51.1 & 84.0 \\
+TNF & 28.1 & $\mathrm{ND}$ \\
+TNF+monensin & 39.3 & $\mathrm{ND}$ \\
\hline
\end{tabular}

U937 cells were cultured for $36 \mathrm{~h}$ in complete medium containing $1 \mu \mathrm{g} / \mathrm{ml}$ monensin and then treated with either $50 \mathrm{ng} / \mathrm{ml}$ anti-Fas or $300 \mathrm{U} / \mathrm{ml}$ TNF for 15 and $22 \mathrm{~h}$, respectively. In other experiments, U937 and Jurkat cells were cultured in medium containing $50 \mu \mathrm{M}$ fumonisin $\mathrm{B}_{1}\left(\mathrm{FB}_{1}\right)$ for $72 \mathrm{~h}$ and then treated with $50 \mathrm{ng} / \mathrm{ml}$ anti-Fas for $15 \mathrm{~h}$. Cells treated with anti-Fas or TNF in the same way but without the inhibitors were used as controls. Cell death was determined by the MTT-assay, as described in Materials and Methods and are the mean of quintuplicate individual determinations. ND, not done monensin-treated cells (Figure 5). However, cell death was similar in both cases (around 58\%, Table 1).

\section{Effect of inhibitors of sphingomyelinases on Fas-induced CPP32 activation}

Western blot analysis of U937 and Jurkat cells treated with cytotoxic anti-Fas antibodies showed the rapid cleavage of the apoptotic protease CPP32, which is known to be associated with its activation (Nicholson et al, 1995; Fernandes-Alnemri et al, 1996). Upon stimulation, the $32 \mathrm{kDa}$-proenzyme was completely cleaved to the active form (Figure 6) producing the characteristic p20, p19 and p17 fragments, corresponding to the different processing of the large $\mathrm{N}$-terminal subunit, and the p12 fragment, correspondent to the small C-terminal subunit (Fernandes-Alnemri et al, 1996). Treatment of U937 cells with TNF caused only a partial cleavage of CPP32, as was also previously observed (Erhardt and Cooper, 1996). Metabolic inhibitors alone did not activate CPP32 (Figure 6), and have no effect on anti-Fas or TNFinduced CPP32 cleavage.

\section{Effect of caspase inhibitors on Fas and TNF-mediated apoptosis}

Contrary to that observed with sphingomyelinase inhibitors, Fas-induced apoptosis in Jurkat cells was prevented by peptide inhibitors of caspases (Table 2). Both Ac-DEVD-CHO (an inhibitor of CPP32-like proteases) and Z-VAD-fmk (which prevents CPP32 activation by inhibition of FLICE/ Mch5/MACH (Fernandes-Alnemri et al, 1996; Muzio et al, 1996)) blocked Fas-mediated apoptosis. Anti-Fas induced apoptosis in U937 cells was also completely blocked by a combination of Ac-DEVD-CHO and YVAD-cmk (Gamen et al, 1996) or Boc-D-fmk, a general inhibitor of caspases (Sarin et al, 1996) (data not shown). Ac-DEVD-CHO, Z-VAD-fmk and Boc-D-fmk did not prevent TNF-induced cell death, as determined by annexin V-labeling, MTT-reduction assay (Table 2) or Trypan blue staining (around $60-70 \%$ of positive cells, irrespective of treatment with peptides). However, these peptide inhibitors completely prevented the development of apoptotic nuclear morphology, i.e., chromatin condensation and fragmentation in U937 cells, as determined by staining with $p$-phenylenediamine and microscopical inspection (Table 2). Other protease inhibitors tested, including calpeptin, a specific calpain inhibitor (Vanags et al, 1996), Z-Asp-2,6-dichlorobenzoyloxymethylketone, 3,4-dichloroisocoumarin and IGA (Anel et al, 1997), were also ineffective in blocking TNF toxicity (not shown). Treatment with a combination of Boc-D-fmk and calpeptin caused a slight reduction $(P<0.05$, two tailed Student's $t$ test) in the proportion of dead cells (Table 2$)$.

\section{Discussion}

Stimulation of sensitive cells with TNF or anti-Fas antibodies induces the activation of acidic and/or neutral sphingomyelinases and the generation of ceramide, which has been associated in many, but not all, cases with apoptosis (Hannum 1994; Wiegmann et al, 1994; Boucher et al, 1995; 
Cifone et al, 1995). Recent and elegant work from the group of $\mathrm{M}$ Kronke has led to the identification of two distinct intracellular domains in the $55 \mathrm{kDa}$ TNFR, and also probably in Fas, which are differentially involved in the activation of neutral or acidic sphingomyelinase (Adam et al, 1996; AdamKlages et al, 1996). Upon TNF ligation, the activated TNFR recruits a $104 \mathrm{kDa}$ protein, named $\mathrm{FAN}$, through the
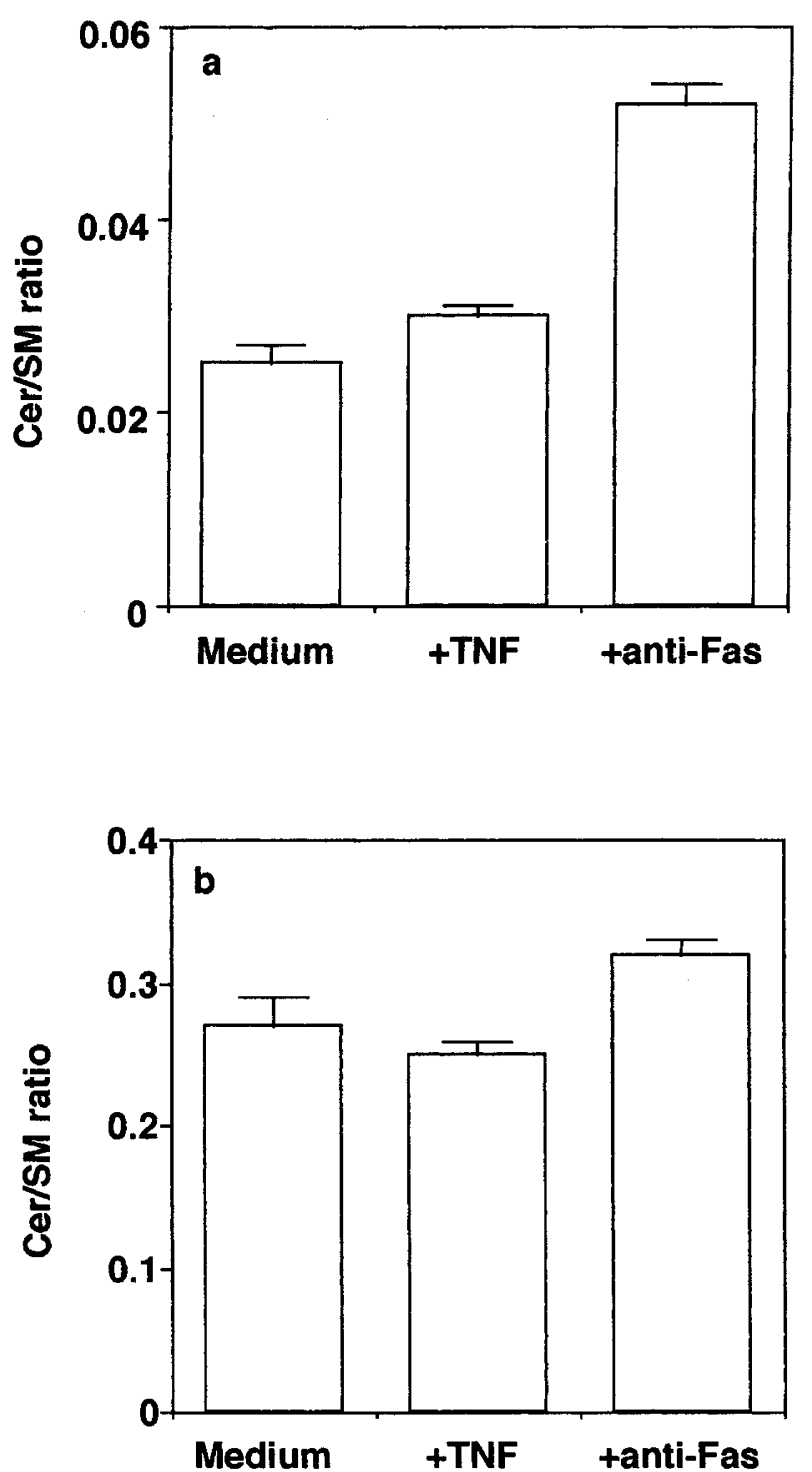

Figure 5 Monensin induces the cellular accumulation of ceramide. U937 cells were labelled for $36 \mathrm{~h}$ in complete medium containing $0.5 \mu \mathrm{Ci} / \mathrm{ml}$ of $\left[1-{ }^{14} \mathrm{C}\right]$ palmitic acid in the absence $(\mathbf{a})$ or presence $(\mathbf{b})$ of $1 \mu \mathrm{g} / \mathrm{ml}$ monensin. Then, cells were resuspended in fresh medium containing $1 \mu \mathrm{g} / \mathrm{ml}$ monensin and $100 \mathrm{ng} / \mathrm{ml}$ anti-Fas or $300 \mathrm{U} / \mathrm{ml}$ TNF. After 15 or $22 \mathrm{~h}$ of incubation, respectively, cell viability was estimated in an aliquot of the cell suspensions and cellular lipids analyzed by TLC. Radioactivity in the ceramide (Cer) and sphingomyelin (SM) fractions was determined by liquid scintillation counting (around 800 and 27000 c.p.m. in controls, respectively). Results are expressed as the ratio of radioactivity in the ceramide to sphingomyelin fractions and are the mean of individual determinations on three separate cultures. Vertical bars indicate S.D. Note the tenfold difference in the Y-axis scale between parts (a) and (b) interaction with a nine aminoacids domain, located upstream of the death domain. The FAN protein in turn mediates the activation of neutral sphingomyelinase and the generation of ceramide at the plasma membrane (Adam-Klages et al, 1996). This ceramide specificially activates a Ser/Thr protein kinase (Yao et al, 1995), recently identified as c-Raf (Huwiler et al, 1996), and initiates the MAPK cascade leading ultimately to cell proliferation/differentiation or generation of inflammatory metabolites. Another member of this pathway may be the ceramide-dependent protein phosphatase $2 \mathrm{~A}$ (Dobrowsky et al, 1993) which control down-regulation of cmyc expression (Wolff et al, 1994) and c-Jun function (González-Reyes et al, 1996). On the other hand, the death domain of TNF receptor, which is responsible for the activation of apoptotic proteases through binding to adaptor proteins such as TRADD (Hsu et al, 1995), also mediates the activation of acid sphingomyelinase (Wiegmann et al, 1994). The ceramide produced by this endosomal/lysosomal enzyme, not by neutral sphingomyelinase, has been clearly implicated in growth arrest and apoptosis induced by irradiation (Santana et al, 1996). Ceramide-mediated apoptosis is thought to be dependent on a distinct subset of kinases, known as stress-activated or c-Jun N-terminal kinases (Xia et al, 1995; Coroneos et al, 1996).

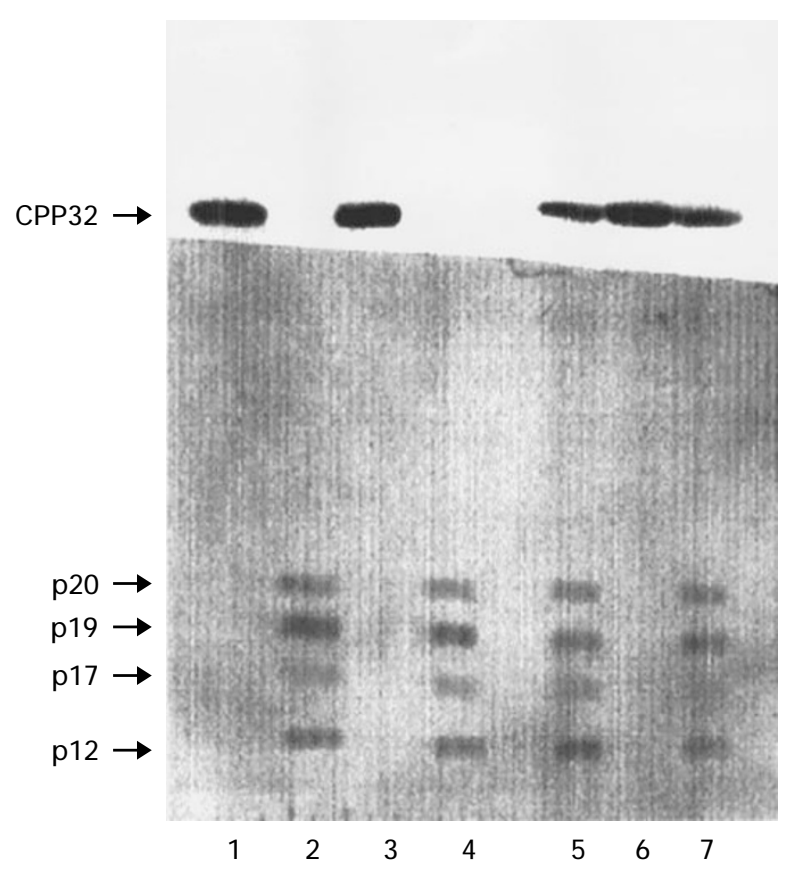

Figure 6 Sphingomyelinase inhibitors do not affect to anti-Fas and TNFinduced CPP32 activation. Jurkat (lanes 1-4) and U937 (lanes 5-7) cells were preincubated for $30 \mathrm{~min}$ in complete medium containing $10 \mu \mathrm{g} / \mathrm{ml}$ cycloheximide, $10 \mu \mathrm{g} / \mathrm{ml}$ monensin and $1 \mathrm{mM}$ EDTA (lanes 3, 4, 6 and 7) or cycloheximide alone (lanes 1, 2 and 5). Then, cells were treated with $100 \mathrm{ng} / \mathrm{ml}$ of anti-Fas antibody (lanes 2 and 4) or $300 \mathrm{U} / \mathrm{ml} \mathrm{TNF}$ (lanes 5 and 7 ) and the incubations prolonged for another $3.5 \mathrm{~h}$ (anti-Fas) or $5 \mathrm{~h}$ (TNF). Proteins from cell lysates were separated by $12 \%$ SDS-PAGE, transferred to nitrocellulose membranes and revealed with a specific anti-CPP32 antibody, as described in Materials and Methods. The upper part of the blot was developed for $5 \mathrm{~min}$, and the lower part was further developed for $6 \mathrm{~h}$ to allow detection of the active protease fragments 
Table 2 Effect of protease inhibitors on Fas or TNF-induced cell death

\begin{tabular}{lccc}
\hline & $\begin{array}{c}\text { PS exposure } \\
\text { (\% of cells) }\end{array}$ & $\begin{array}{c}\text { Apoptotic } \\
\text { nuclei } \\
\text { (\% of cells) }\end{array}$ & $\begin{array}{c}\text { Cell death } \\
\text { (\%) }\end{array}$ \\
\hline Jurkat & & & \\
$\quad$ Control & $1.8 \pm 0.1$ & 1.9 & 0 \\
+anti-Fas & $62.6 \pm 2.0$ & 71.2 & $66.1 \pm 3.9$ \\
+anti-Fas+Ac- & $3.0 \pm 0.2$ & 2.6 & $2.6 \pm 0.5$ \\
$\quad$ DEVD-CHO & & & \\
+anti-Fas+Z-VAD- & $1.6 \pm 0.2$ & 1.0 & $0.1 \pm 4.0$ \\
$\quad$ fmk & & & \\
U937 & $1.1 \pm 0.5$ & 3.0 & 0 \\
Control & $42.9 \pm 2.5$ & 64.0 & $51.6 \pm 3.0$ \\
+TNF & $41.0 \pm 3.0$ & ND & $48.8 \pm 5.5$ \\
+TNF+Ac-DEVD- & & & \\
$\quad$ CHO & $43.5 \pm 3.5$ & 2.1 & $63.9 \pm 2.7$ \\
+TNF+Z-VAD-fmk & $54.3 \pm 4.3$ & 4.1 & $52.7 \pm 2.0$ \\
+TNF+Boc-D-fmk & ND & ND & $50.5 \pm 3.9$ \\
+TNF+calpeptin & $32.5 \pm 1.7$ & 3.9 & $41.0 \pm 1.5$ \\
+TNF+Boc-D-fmk & & & \\
$\quad$ +Calpeptin & & & \\
\hline
\end{tabular}

Jurkat and U937 cells were preincubated or not (controls) for $3 \mathrm{~h}$ with Ac-DEVD$\mathrm{CHO}(600 \mu \mathrm{M})$ or $1 \mathrm{~h}$ with Z-VAD-fmk $(100 \mu \mathrm{M})$, Boc-D-fmk $(50 \mu \mathrm{M})$ or calpeptin $(10 \mu \mathrm{M})$, alone or in combination. Apoptosis was then induced by addition of either $50 \mathrm{ng} / \mathrm{ml}$ anti-Fas or $300 \mathrm{U} / \mathrm{ml}$ TNF and incubation for $15 \mathrm{~h}$ or $20 \mathrm{~h}$, respectively. Cell death was determined by the MTT-assay, cells showing apoptotic nuclei by staining with p-phenylenediamine and phosphatidylserine (PS) exposure by annexin V-FITC binding, as described in Materials and Methods. Results are the mean \pm S.D. of at least four independent determinations. None of the peptide inhibitors at the concentrations used was cytotoxid for the cells per se. ND, not done

Fas is a membrane protein that also possesses a death domain, homologous to that of $55 \mathrm{kDa}$ TNFR (Tartaglia et al, 1993). When cross-linked with antibodies or by FasL, the Fas death domain binds to several adaptor proteins which in turn bind and activate apoptotic proteases (caspases) (Boldin et al, 1996; Fernandes-Alnemri et al, 1996; Muzio et al, 1996). It has also been described that acidic and/or neutral sphingomyelinases became activated during Fas-mediated apoptosis and the available evidence suggests that, as in the case of TNF receptor, different regions of Fas may mediate the activation of each type of sphingomyelinases (Cifone et al, 1993; Adam-Klages et al, 1996). It remains unclear, however, which of these enzymes is relevant for Fas-mediated apoptosis (Cifone et al, 1993; Tepper et al, 1995; Gamen et al, 1996).

To address the question of the relative contribution of ceramide as a mediator of TNF and Fas-mediated apoptosis, we induced these processes in sensitive cells treated with inhibitors of acidic and/or neutral sphingomyelinases. We also evaluated the induction of apoptosis in cells treated with drugs that greatly increase or decrease the intracellular amount of ceramide. The results obtained indicate a lack of correlation between cellular ceramide generation and the extent of Fas-or TNF-induced apoptosis. Rapid apoptosis induced by TNF and anti-Fas in the presence of cycloheximide was associated only with a slight increase in cellular ceramide content (Figure 3). Cell death was not prevented by inhibitors of neutral and acidic sphingomyelinases (Figure 1) or of ceramide synthase (Figure 2). A similar lack of augmentation of the cell ceramide content in rapid Fas-mediated apoptosis induced by T-cell effectors expressing FasL (Anel et al, 1997), in apoptosis induced with anti-Fas antibodies in murine thymocytes (Redondo et al, 1996) and in murine hepatocytes (Rouquet et al, 1996) has also been observed. In addition, a substantial reduction in the cell ceramide and sphingomyelinase content by chronic treatment with $\mathrm{FB}_{1}$ did not affect to TNF- or anti-Fas cytotoxicity (Figure 4).

There are several differences, that still remain unexplained, concerning the mechanisms of apoptosis induced by Fas, TNF or ceramide. Fas or TNF-induced apoptosis is blocked by the viral serpin CrmA (Tewari and Dixit, 1995) but it is not prevented by inhibitors of protein kinases and phosphatases (Wright et al, 1992; Anel et al, 1994; Schulze-Osthoff et al, 1994; Ji et al, 1995). On the contrary, ceramide-dependent activities are sensitive to kinase and phosphatase inhibitors (Wright et al, 1992; Yao et al, 1995) and ceramide-mediated apoptosis is not blocked by Ac-DEVD-CHO (Gamen et al, 1996) or CrmA (Geley et al, 1997). Moreover, TNF causes no toxicity in Jurkat and endothelial cells (Gamen et al, 1996; Slowik et al, 1996) (where it induces activation of NF- $\kappa \mathrm{B}$ (Slowik et al, 1996; Van Antwerp et al, 1996)), differentiation in HL-60 cells (Greenblatt and Elias, 1992) and apoptosis in U937 cells (Gamen et al, 1996), in spite of causing comparable increases in the cell ceramide content in all these cell types (Kolesnick and Golde, 1994). However, addition of ceramide to culture media promotes apoptotic cell death in all Jurkat, HL-60 and U937 cell lines (Jarvis et al, 1994; Cuvillier et al, 1996; Gamen et al, 1996). In addition, induction of sphingomyelinase hydrolysis may be nonspecifically triggered by the Fc region of any IgG, without causing any concomitant toxicity (Glick and Barenholz, 1996). The notion that the apoptotic pathways triggered by Fas and ceramide are different is also underscored by the fact that ceramide causes apoptosis in Jurkat- $\rho^{\circ}$ cells (Gamen et al, 1996) which lack the expression of the apoptotic protease CPP32 (Gamen S., Anel A. and Naval J., unpublished work), the main mediator of Fas-based apoptosis in Jurkat cells (Gamen et al, 1996; Schlegel et al, 1996).

While these results indicate that ceramide generation is not essential for Fas- and TNF-induced apoptosis, these processes were associated with the cleavage and activation of the caspase CPP32, especially in the case of Fas-induced apoptosis (Figure 5). Apoptosis via Fas is mediated by CPP32-like proteases, since it is prevented by Ac-DEVD-CHO (Anel et al, 1996; 1997; Gamen et al, 1996), which inhibits CPP32 activity, or by caspase inhibitors that block CPP32 activation (Table 2). The situation in the case of TNF-induced apoptosis is rather different. TNF also induces the cleavage of CPP32, but to a lesser extent than anti-Fas (Figure 5) and Ac-DEVD-CHO, while blocking CPP32 activity, did not prevent TNF-induced death of U937 cells. However, Z-VAD-fmk or Boc-D-fmk do effectively inhibit the characteristic apoptotic nuclear morphology (chromatin condensation and fragmentation) induced by TNF. A similar result, inhibition of nuclear fragmentation but not U937 cell death, has been recently 
reported (Vanags et al, 1996). TNF-induced apoptosis has been reported to be prevented by the serpin $\operatorname{CrmA}$ in other cell lines, suggesting the implication of caspases (Tewari and Dixit, 1995), but the criteria followed for the inhibition of apoptosis was the absence of apoptotic nuclei. The present and previous data (Vanags et al, 1996) suggest that the known caspases alone do not seem to be the sole mediators of TNF-induced apoptosis, at least in U937 cells.

One of the consequences of Fas-induced apoptosis is the progressive cellular accumulation of ceramide (Tepper et al, 1995; Chinnayian et al, 1996; Gamen et al, 1996). This increase in ceramide levels is dependent on CPP32like caspases, since the blockade of CPP32-like activity prevents both cell death and ceramide accumulation (Gamen et al, 1996). Cellular ceramide levels are also augmented during TNF-induced apoptosis (Erhardt and Cooper, 1996) and cell transfection with $\operatorname{CrmA}$ prevents again caspase activation and ceramide generation (Dbaibo et al, 1997). Exogenous ceramide is able to induce apoptosis in virtually all kinds of cultured cells and ceramide produced by acid sphingomyelinase is a key mediator of apoptosis induced by irradiation (Santana et al, 1996). Therefore, ceramide generation in late steps of TNF and Fas-mediated apoptosis could contribute to the spread of the death signal. In this respect, ceramide has been recently reported to be rather a 'gauge' or a 'sensor' than an 'executor' of apoptosis induced by physiological means (Zhang et al, 1996).

In conclusion, while ceramide does not seem to be an essential downstream mediator of TNF and Fas-mediated apoptosis, it is generated after TNF receptor and Fas triggering and can function as a molecular sensor of apoptosis and/or participate in the secondary spread of the death signal.

\section{Materials and Methods}

\section{Materials}

Fumonisin $\mathrm{B}_{1}\left(\mathrm{FB}_{1}\right)$, from Fusarium moniliforme, neutral sphingomyelinase from Staphylococcus aureus, chloroquine, monensin, cycloheximide, EDTA and 3-[4,5-dimethylthiazol-2-yl]-2,5-diphenyl-tetrazolium bromide (MTT) were products from Sigma (Madrid, Spain). Human recombinant TNF- $\alpha$ was kindly provided by The National Institute for Biological Standards and Control (Hertfordshire, UK). Cytotoxic mouse monoclonal anti human Fas IgM antibody (clone $\mathrm{CH}-11$ ) was from UBI (Lake Placid, USA) and mouse IgG2a anti human CPP32 (clone 19) from Transduction Laboratories (Affiniti, Mamhead, UK). Acetyl-AspGlu-Val-Asp aldehyde (Ac-DEVD-CHO), benzyloxycarbonyl-Val-AlaAsp-fluoromethylketone (Z-VAD-fmk) were from Bachem (Bubendorf, Switzerland). t-butyloxycarbonyl-Asp-fluoromethylketone (Boc-D-fmk) was from Enzyme Systems (Dublin, CA, USA) and benzyloxycarbonyldipeptidyl aldehyde (Calpeptin) from Novabiochem (Läufelfingen, Switzerland).

\section{Cell culture and analysis of cell death}

Human promonocytic leukemia U937 and the Jurkat T-cell leukemia (ATCC, clone E6.1) were cultured in RPMI 1640 medium (Biowhittaker, Barcelona, Spain) supplemented with $5 \%$ fetal calf serum, L-glutamine and penicillin/streptomycin (hereafter, complete medium), using standard cell culture procedures. For cell death assays, cells were seeded in flat-bottom, 96-well plates at an initial density of $3-5 \times 10^{5} \mathrm{cells} / \mathrm{ml}(100 \mu \mathrm{l} / \mathrm{well})$, and cultured for $3-6 \mathrm{~h}$ in complete medium containing $10 \mu \mathrm{g} / \mathrm{ml}$ cycloheximide and $300 \mathrm{U} / \mathrm{ml}$ TNF or $100 \mathrm{ng} / \mathrm{ml}$ anti-Fas antibodies. The effect of several drugs, which interfere with ceramide metabolism, on TNF and Fasmediated apoptosis was also evaluated. These were $\mathrm{FB}_{1}$ (25$50 \mu \mathrm{M}$ ), an inhibitor of ceramide synthase (Jaffrézou et al, 1996), the lysosomotropic agents chloroquine $(10 \mu \mathrm{M})$, ammonium chloride $(8 \mathrm{mM})$ and monensin $(1-10 \mu \mathrm{g} / \mathrm{ml})$, all of which inhibit acid sphingomyelinase activity (Wiegmann et al, 1994; Tepper et al, 1995; Andrieu et al, 1996), and EDTA (1 mM), a $\mathrm{Ca}^{2+}$ - and $\mathrm{Mg}^{2+}$. chelator which inhibits the activity of neutral, $\mathrm{Mg}^{2+}$-dependent, sphingomyelinase (Futerman et al, 1990). Chloroquine was dissolved in RPMI medium, EDTA and $\mathrm{FB}_{1}$ in PBS and monensin in ethanol. At the doses used $(0.1 \%$, final concentration), ethanol had no effect on cell proliferation. Cells were incubated with inhibitors for $30 \mathrm{~min}$ prior to the addition of TNF or anti-Fas antibodies.

In other experiments, Jurkat and U937 cells were also cultured for 3 days in complete medium containing $50 \mu \mathrm{M} \mathrm{FB}_{1}$ to deplete cells of sphingomyelin and ceramide (Hidari et al, 1996; Jaffrézou et al, 1996). Conversely, the intracellular levels of ceramide were raised by culturing U937 cells for $36 \mathrm{~h}$ in medium containing $1 \mu \mathrm{g} / \mathrm{ml}$ monensin (Kallen et al, 1993). Then $50 \mathrm{ng} / \mathrm{ml}$ anti-Fas or $300 \mathrm{U} / \mathrm{ml}$ TNF were added to cultures and cells incubated for another 15 or $20 \mathrm{~h}$, respectively. Cultures containing the same amounts of drugs, but no TNF or anti-Fas, were used as controls. To assess the effect of caspase inhibitors on Fas and TNF-mediated apoptosis cells were incubated for $1 \mathrm{~h}$ with either Z-VAD-fmk $(100 \mu \mathrm{M})$, Boc-D-fmk (50$100 \mu \mathrm{M})$ or calpeptin $(10 \mu \mathrm{M})$ or for $3 \mathrm{~h}$ with Ac-DEVD-CHO $(600 \mu \mathrm{M})$, prior to the treatment with anti-Fas or TNF, respectively. In all cases, cell viability was determined by the Trypan blueexclusion test and by a modification of the MTT-reduction method of Mosmann (Alley et al, 1988). Percentage of cell death was calculated as follows:

$$
\text { Cell death }(\%)=\left(1-\frac{A_{550}(\text { samples })-A_{550}(\text { blanks })}{A_{550}(\text { controls })-A_{550}(\text { blanks })} \times 100\right.
$$

Cell death was also quantified by measuring phosphatidylserine exposure by using annexin V-FITC (Bender Medsystems, Germany), according to the instructions of manufacturer. Briefly, cells were incubated in the dark with $0.5 \mu \mathrm{g} / \mathrm{ml}$ annexin V-FITC in binding buffer (10 mM HEPES/NaOH, pH 7.4; $140 \mathrm{mM} \mathrm{NaCl}$, $2.5 \mathrm{mM} \mathrm{CaCl}_{2}$ ) at $4{ }^{\circ} \mathrm{C}$ for $30 \mathrm{~min}$, washed and annexin binding analyzed in an Epics XL-MCL (Coulter, Spain) flow cytometer. Nuclear apoptosis (chromatin condensation and fragmentation) in cells treated with anti-Fas or TNF was evaluated by staining cytocentrifuge-prepared cell smears with the nuclear stain $p$-phenylenediamine, as described the previously (Gamen et al, 1996).

\section{Analysis of Fas and TNFR expression}

The membrane expression of Fas and the $55 \mathrm{kDa}$ TNFR was analyzed by flow cytometry by using the mouse monoclonal antibodies anti human Fas (IgG2b, clone SM1/23) and anti human $55 \mathrm{kDa}$ TNFR (IgG2a, clone H398) both from Bender Medsystems. Cells $\left(5 \times 10^{5}\right.$ in $\left.50 \mu \mathrm{l}\right)$ were incubated at $4^{\circ} \mathrm{C}$ in PBS containing $0.2 \%$ BSA and $0.02 \%$ sodium azide and $5 \mu \mathrm{g} / \mathrm{ml}$ of the corresponding antibody for $1 \mathrm{~h}$. Then, cells were washed with 
PBS, incubated with a 1:250 dilution of a FITC-labelled goat anti mouse IgG (Caltag, Barcelona, Spain) for $30 \mathrm{~min}$, fixed with $1 \%$ paraformaldehyde in PBS, pH 7.4, for $15 \mathrm{~min}$, and 5000 cells/ sample analyzed by flow cytometry.

\section{Analysis of CPP32 activation}

CPP32 activation was evaluated by Western blot analysis of cell homogenates with a specific anti-human CPP32 antibody. Jurkat and U937 cells $\left(5 \times 10^{6}\right.$ in $1 \mathrm{ml}$ of RPMl 1640 medium containing $1 \mathrm{mg} / \mathrm{ml}$ $\mathrm{BSA}$ and $10 \mu \mathrm{g} / \mathrm{ml}$ cycloheximide) were treated, in the presence or absence of a combination of $1 \mathrm{mM}$ EDTA and $10 \mu \mathrm{g} / \mathrm{ml}$ monensin, at $37^{\circ} \mathrm{C}$ with $100 \mathrm{ng} / \mathrm{ml}$ anti-Fas for $3.5 \mathrm{~h}$ or with $300 \mathrm{U} / \mathrm{ml}$ TNF for $5 \mathrm{~h}$, respectively. At the end of incubations, cells were recovered by centrifugation at $4{ }^{\circ} \mathrm{C}$, washed twice with cold PBS and lysed in $1 \mathrm{ml}$ of lysis buffer $(50 \mathrm{mM}$ Tris/ $\mathrm{HCl}, \mathrm{pH} 7.6$, containing $1 \%$ Triton $\mathrm{X}-100$, $0.15 \mathrm{M} \mathrm{NaCl}, 1 \mathrm{mM}$ EDTA, $30 \mathrm{mM} \mathrm{NaF}, 10 \mu \mathrm{g} / \mathrm{ml}$ leupeptin and $1 \mathrm{mM}$ PMSF), as previously described (Alava et al, 1992). Cell lysates were centrifuged $\left(4^{\circ} \mathrm{C}, 12000 \mathrm{~g}, 15 \mathrm{~min}\right)$ and proteins separated by SDSPAGE in a SDS/12\%-polyacrylamide gel under reducing conditions and transferred to nitrocellulose membranes (Hybond-C extra, Amersham, Madrid, Spain). Membranes were then sequentially incubated with $50 \mathrm{ng} / \mathrm{ml}$ anti-CPP32 antibody in PBS containing 5\% BSA and with $0.2 \mu \mathrm{g} / \mathrm{ml}$ goat anti-mouse IgG coupled to alkaline-phosphatase (Sigma) for $1 \mathrm{~h}$ and revealed with BCIP/NBT. After $5 \mathrm{~min}$ of colour development, blotting membranes were cut after the position of the $32 \mathrm{kDa}$ bands, corresponding to the inactive CPP32 protease, and the portion of blotting membrane containing the p20 to p12 fragments of the active protease further developed for $6 \mathrm{~h}$ to allow their detection.

\section{Analysis of ceramide and sphingomyelin levels}

Cells $\left(5 \times 10^{6}\right.$ in $10 \mathrm{ml}$ of complete medium) were labelled for $48 \mathrm{~h}$ with $5 \mu \mathrm{Ci}$ of $\left[1-{ }^{14} \mathrm{C}\right]$ palmitic acid (specific activity $55.0 \mathrm{mCi} / \mathrm{mmol}$, Amersham) bound to fatty acid-free serum albumin (1:1, molar ratio). Cells were harvested, resuspended at $5 \times 10^{5} \mathrm{cell} / \mathrm{s} / \mathrm{ml}$ in complete medium containing $10 \mu \mathrm{g} / \mathrm{ml}$ cycloheximide or the same medium plus $1 \mathrm{mM}$ EDTA and $10 \mu \mathrm{g} / \mathrm{ml}$ monensin, and preincubated for $30 \mathrm{~min}$. Then, Jurkat cells were treated with $100 \mathrm{ng} / \mathrm{ml}$ anti-Fas antibody for $3.5 \mathrm{~h}$, and U937 cells with $300 \mathrm{U} / \mathrm{ml}$ TNF for $6 \mathrm{~h}$. In other experiments, Jurkat and $\mathrm{U} 937$ cells were cultured in complete medium containing $50 \mu \mathrm{M} \mathrm{FB}_{1}$ for $24 \mathrm{~h}$. Then, $0.5 \mu \mathrm{Ci} / \mathrm{ml}$ of $\left[1-{ }^{14} \mathrm{C}\right]$ palmitic acid were added to cultures and incubation prolonged for a further $48 \mathrm{~h}$ period (Jaffrézou et al, 1996). Jurkat and U937 cells were also labelled with $\left[1-{ }^{14} \mathrm{C}\right]$ palmitic acid in medium containing $1 \mu \mathrm{g} / \mathrm{ml}$ monensin for $36 \mathrm{~h}$. Then, $\mathrm{FB}_{1}$ and monensin-treated cells were incubated with $50 \mathrm{ng} / \mathrm{ml}$ anti-Fas or $300 \mathrm{U} / \mathrm{ml}$ TNF in fresh medium containing the same concentration of either $\mathrm{FB}_{1}$ or monensin and incubated for $15 \mathrm{~h}$. In all cases, at the end of incubations, cells were harvested, counted and washed with ice-cold PBS. Total cell lipids were extracted with chloroform/methanol $(2: 1, \mathrm{v} / \mathrm{v})$ (Anel et al, 1992), and cholesterol, ceramide and sphingomyelin resolved by TLC in silica gel G plates $(20 \times 20 \mathrm{~cm})$, essentially as described previously (Gamen et al, 1996). Briefly, the radioactivity recovered in cell lipids was determined in aliquots of chloroform extracts and equal amounts of radioactivity (around $3 \times 10^{5}$ c.p.m.) for each sample were applied to TLC plates. Sequential one-dimensional TLC was performed with chloroform/ methanol/water $(60: 30: 5, \mathrm{v} / \mathrm{v})$ up to $12 \mathrm{~cm}$ from the bottom of the plate followed by a second development to its full length with $n$-hexane/ diethyl ether/acetic acid $(80: 20: 2, \mathrm{v} / \mathrm{v})$. Radiolabelled lipids were located by autoradiography (Hyperfilm $\beta$-max, Amersham) at room temperature for 2 days and radioactivity quantitated by liquid scintillation counting. Results were expressed as ceramide to sphingomyelin ratio.
Similar results were obtained when ceramide levels were normalised to cholesterol or total phospholipid levels (Gamen et al, 1996).

\section{Acknowledgements}

This work was supported by grant no. PB 96-0355 from Dirección General de Enseñanza Superior and contract ERBFMBICT 960742 from CEE. SG was recipient of a fellowship from the Gobierno de Navarra.

\section{References}

Adam D, Wiegmann K, Adam-Klages S, Ruff A and Krönke M (1996) A novel cytoplasmic domain of the 55 tumor necrosis factor receptor initiates the neutral sphingomyelinase pathway. J. Biol. Chem. 271: 14617-14622

Adam-Klages S, Adam D, Wiegmann K, Struve S, Kolanus W, Schneider-Mergener J and Krönke M (1996) FAN, a novel WD-repeat protein, couples the p55 TNFreceptor to neutral sphingomyelinase. Cell 86: 937-947

Alava MA, DeBell KE, Conti A, Hoffman Tand Bonvini E (1992) Increased intracellular cyclic AMP inhibits inositol phospholipid hydrolysis induced by perturbation of the T cell receptor/CD3 complex but not by G-protein stimulation. Association with protein kinase A phosphorylation of phospholipase $C-\gamma 1$. Biochem. J. 284: $189-199$

Alley MC, Scudiero DA, Monks A, Hursey ML, Czerwinski MJ, Fine D, AbbotBJ, Mayo JG, Shoemaker RH and Boyd MR (1988) Sensibility of drug screening with panels of human tumor cell lines using microculture tetrazolium assay. Cancer Res. 46: 589-601

Andrieu N, Salvayre Rand Levade T (1996) Comparative study of the metabolic pools of sphingomyelin and phosphatidylcholine sensitive to tumor necrosis factor. Eur. J. Biochem. 236: 738-745

Anel A, Naval J, Desportes P, Gonzalez B, Uriel J and Piñeiro A (1992) Increased cytotoxicity of polyunsaturated fatty acids on human tumoral $B$ and $T$-cell lines compared with normal lymphocytes. Leukemia 6: 680-688

Anel A, Buferne M, Boyer C, Schmitt-Verhulst AM and Golstein P (1994) T cell receptor-induced Fas ligand expression in cytotoxic $T$ lymphocyte clones is blocked by protein tyrosine kinase inhibitors and cyclosporin A. Eur. J. Immunol. 24: $2469-2476$

Anel A, Gamen S, Alava MA, Schmitt-Verhulst AM, Piñeiro A and Naval J (1996) Role of oxidative damage and ICE-like proteases in Fas-based cytotoxicity exerted by effector T cells. Int. Immunol. 8: 1173-1183

Anel A, Gamen S, Alava MA, Schmitt-Verhulst AM, Piñeiro A and Naval J (1997) Inhibition of CPP32-like proteases prevents granzyme B- and Fas-, but not granzyme A-based cytotoxicity exerted by CTL clones. J. Immunol. 158: 1999 2006

Boldin MP, Goncharov TM, Goltsev YV and Wallach D (1996) Involvement of MACH, a novel MORT1/FADD-interacting protease, in Fas/APO-1 and TNF receptorinduced cell death. Cell 85: 803-815

BoucherLM, Wiegmann K, Fütterer A, PfefferK, Machleidt T, Schütze S, MakTW and Krönke M (1995) CD28 signals through acidic sphingomyelinase. J. Exp. Med. 181: $2059-2068$

Casciola-Rosen L, Nicholson DW, Chong T, Rowan KR, Thornberry NA, Miller DK and Rosen A (1996) Apopain/CPP32 cleaves proteins that are essential for cellular repair : A fundamental principle of apoptotic death. J. Exp. Med. 183: $1957-1964$

Cifone MG, De Maria R, Roncaioli P, Rippo MR, Azuma M, Lanier LL, Santoni A and Testi R (1993) Apoptotic signaling through CD95 (Fas/Apo-1) activates an acidic sphingomyelinase. J. Exp. Med. 177: 1547-1552

Cifone MG, Roncaioli P, De Maria R, Camarda G, Santoni A, Ruberti G and Testi R (1995) Multiple pathways originate at the Fas/APO-1 (CD95) receptor: sequential involvement of phosphatidylcholine-specific phospholipase $\mathrm{C}$ and acidic sphingomyelinase in the propagation of the apoptotic signal. EMBO J. 14 $5859-5868$

Coroneos E, Wang Y, Panuska JR, Templeton DJ and Kester M (1996) Sphingolipid metabolites differentially regulate extracellular signal-regulated kinase and stress-activated protein kinase cascades. Biochem. J. 316: 13-17

Cuvillier O, Pirianov G, Kleuser B, Vanek PG, Coso OA, Gutkind JS and Spiegel S (1996) Suppression of ceramide-mediated programmed cell death by sphingosine-1-phosphate. Nature 381: 800-803 
Chinnayian AM, Tepper CG, Seldin MF, O'Rourke K, Kischkel FC, Hellbard S, Krammer PH, Peter ME and Dixit VM (1996) FADD/MORT1 is a common mediator of CD95 (Fas/AP01) and tumor necrosis factor receptor-induced apoptosis. J. Biol. Chem. 271: 4961-4965

Das DVM, Cook HW and Spence MW (1984) Evidence that neutral sphingomyelinase of cultured murine neuroblastoma cells is oriented externally on the plasma membrane. Biochim. Biophys. Acta. 777: 339-342

Dbaibo GS, Perry DK, Gamard CJ, Platt R, Poirier GG, Obeid LM and Hannun YA (1997) Cytokine response modifier $\mathrm{A}(\mathrm{CrmA})$ inhibits ceramide formation in response to tumour necrosis factor (TNF)- $\alpha$ : CrmA and Bcl-2 target distinct components in the apoptotic pathway. J. Exp. Med. 185: 481-490

Dobrowsky RT, Kamibayashi C, Mumby MC and Hannun YA (1993) Ceramide activates heterotrimeric protein phosphatase2A. J. Biol. Chem. 268: 1552315530

Erhardt P and Cooper GM (1996) Activation of the CPP32 apoptotic protease by distinct signaling pathways with differential sensitivity to Bcl-x. J. Biol. Chem. 271: $17601-17604$

Fernandes-Alnemri T, Armstrong RC, Krebs J, Srinivasula SM, Wang L, Bullrich F, Fritz LC, Trapani JA, Tomaselli KJ, Litwack G and Alnemri ES (1996) In vitro activation of CPP32 and Mch3 by Mch4, a novel human apoptotic cysteine protease containing two FADD-like domains. Proc. Natl. Acad. Sci. USA 93: 7464-7469

Futerman AH, Stieger B, Hubbard AL and Pagano RE (1990) Sphingomyelin synthesis in rat liver occurs predominantly at the cis and medial cisternae of the Golgi apparatus. J. Biol. Chem. 265: 8650-8657

Gamen S, Marzo I, Anel A, Piñeiro A and Naval J (1996) CPP32 inhibition prevents Fas-induced ceramide generation and apoptosis in human cells. FEBS. Lett. 390 233-237

Geley S, Hartmann BL and Kofler R (1997) Ceramides induce a form of apoptosis in human acute lymphoblastic leukemia cells that is inhibited by $\mathrm{Bcl}-2$, but not by CrmA. FEBS Lett. 400: 15-18

Glick D and Barenholz Y (1996) IgG immunoglobulins induce activation of the sphingomyelin cycle in HL-60 cells. FEBS Lett. 394: 237-240

González-Reyes J, González-Robayna I, Santana P, Hernández I, Quintana J, Estévez F, Fanjul LF and Ruiz de Galarreta CM. (1996) c-Jun is a downstream target for ceramide-activated protein phosphatase in A431 cells. J. Biol. Chem. 271: $21375-21380$

Greenblatt MS and Elias $L$ (1992) The type B receptor for tumor necrosis factor- $\alpha$ mediates DNA fragmentation in HL-60 and U937 cells and differentiation in HL60 cells. Blood 80: 1339-1346

Greidinger EL, Miller DK, Yamin TT, Casciola-Rosen L and Rosen A (1996) Sequential activation of three distinct ICE-like activities in Fas-ligated Jurkat cells. FEBS Lett. 390: 299-303

Hannun YA (1994) The sphingomyelin cycle and the second messenger function of ceramide. J. Biol. Chem. 269: 3125-3128

Henkart PA (1996) ICE family proteases : mediators of all apoptotic cell death? Immunity 4: 195-201

Hidari KIPJ, Ichikawa S, Fujita T, Sakiyama H and Hirabayashi Y (1996) Complete removal of sphingolipids from the plasma membrane disrupts cell to substratum adhesion of mouse melanoma cells. J. Biol. Chem. 271: 14636-14641

Hsu H, Xiong J and Goeddel DV (1995) The TNF receptor 1-associated protein TRADD signals death and NF- $k$ B activation. Cell 81: 495-504

Huwiler A, Brunner J, Hummel R, Vervoordeldonk M, Stabel S, van den Bosch H and Pfeilschifter J (1996) Ceramide-binding and activation defines protein kinase cRaf as a ceramide-activated protein kinase. Proc. Natl. Acad. Sci. USA 93 $6959-6963$

Jaffrézou JP, Levade T, Bettaïeb A, Andrieu N, Bezombes C, MaestreN, Vermeersch S, Rousse A and Laurent G (1996) Daunorubicin-induced apoptosis: triggering of ceramide generation through sphingomyelin hydrolysis. EMBO J. 15: $2417-$ 2424

Ji L, Zhang G, Uematsu S, Akahori Y and Hirabayashi Y (1995) Induction of apoptotic DNA fragmentation and cell death by natural ceramide. FEBS Lett. 358: 211 214

Kallen KJ, Quinn P and Allan D (1993) Monensin inhibits synthesis of plasma membrane sphingomyelin by blocking transport of ceramide through the Golgi : evidence for the two sites of sphingomyelin synthesis in BHK cells. Biochim. Biophys. Acta 1166: 305-308

Kolesnick R and Golde DW (1994) The sphingomyelin pathway in tumor necrosis factor and interleukin-1 signaling. Cell 77: 325-328
Murphy E, Steenberg C, Levy LA, Raju B and London RE (1989) Cytosolic free magnesium levels in ischemic rat heart. J. Biol. Chem. 264: 5622-5627

Muzio M, Chinnayian AM, Kischkel FC, O'Rourke K, Shevchenko A, Ni J, Scaffidi C, Bretz JD, Zhang M, Gentz R, Mann M, Krammer PH, Peter ME and Dixit VM (1996) FLICE, a novel FADD-homologous ICE/CED-3-like protease, is recruited to the CD95 (Fas/APO-1) death-inducing signaling complex. Cell 85: 817-827

Nicholson DW, Ali A, Thornberry NA, Vaillancourt JP, Ding CK, Gallant M, Gareau Y, Griffin PR, Labelle M, Lazebnik YA, Munday NA, Raju SM, Smulson ME, Yamin TT, Yu VL and Miller DK (1995) Identification and inhibition of the ICE/CED-3 protease necessary for mammalian apoptosis. Nature 376: 37-43

Redondo C, Flores I, González A, Nagata S, Carrera AC, Merida I and Martínez AC (1996) Linomide prevents the lethal effect of anti-Fas antibody and reduces Fasmediated ceramide production in mouse hepatocytes. J. Clin. Invest. 98: 12451252

Rouquet N, Carlier K, Briand P, Wiels J and Joulin V (1996) Multiple pathways of Fasinduced apoptosis in primary culture of hepatocytes. Biochem. Biophys. Res. Commun. 229: 27-35

Santana P, Peña LA, Haimovitz-Friedman A, Martin S, Green D, McLoughlin M Cordon-Cardo C, Schuchman EH, Fuks Z and Kolesnick R (1996) Acid sphingomyelinase-deficient human lymphoblasts and mice are defective in radiation-induced apoptosis. Cell 86: $189-199$

Sarin A, Wu ML and Henkart PA (1996) Different interleukin-1 $\beta$ converting enzyme (ICE) family protease requirements for the apoptotic death of T lymphocytes triggered by diverse stimuli. J. Exp. Med. 184:2445-2450

Schlegel J, Peters I, Orrenius S, Miller DK, Thornberry NA, Yamin TT and Nicholson DW (1996) CPP32/apopain is a key ICE-like protease involved in Fas-mediated apoptosis. J. Biol. Chem. 271: 1841-1844

Schulze-OsthoffK, Krammer PH and DrögeW (1994) Divergent signalling via APO-1/ Fas and the TNF receptor, two homologous molecules involved in physiological cell death. EMBO J. 13: 4587-4596

Slowik MR, DeLuca LG, Min W and PoberJS (1996)Ceramide is not a signal for tumor necrosis factor-induced gene expression but does cause programmed cell death in human vascular endothelial cells. Circ. Res. 79: 736 -747

Tartaglia LA, Ayres TM, Wong GHW and Goeddel DV (1993) A novel domain within the $55 \mathrm{kd}$ TNF receptor signals cell death. Cell 74: 845-853

Tepper CG, Jayadev S, Liu B, Bielawska A, Wolff R, Yonehara S, Hannun YA and Seldin MF (1995) Role of ceramide as an endogenous nediator of Fas-induced cytotoxicity. Proc. Natl. Acad. Sci. USA 92: 8443-8447

Tewari M and Dixit VM. (1995) Fas- and tumor necrosis factor-induced apoptosis is inhibited by the poxvirus CrmA gene product. J. Biol. Chem. 270: 3255-3260

Tewari M, Quan LT, O'Rourke K, Desnoyers S, Zeng Z, Beidler DR, Poirier GG Salvesen GS and Dixit VM (1995) Yama/CPP32 $\beta$, a mammalian homolog of CED-3, is a CrmA-inhibitable protease that cleaves the death substrate poly(ADP-ribose) polymerase. Cell 81: 801-809

Van Antwerp DJ, Martin SJ, Kafri T, Green DR and Verma IM (1996) Suppression of TNF- $\alpha$-induced apoptosis by NF- $\kappa$ B. Science 274: 787-789

Vanags DM, Pörn-Ares MI, Coppola S, Burgess DH and Orrenius S. (1996) Protease involvement in fodrin cleavage and phosphatidylserine exposure in apoptosis. J. Biol. Chem. 271: 31075-31085

Wiegmann K, Schütze S, Machleidt T, Witte D and Krönke M (1994) Functional dichotomy of neutral and acidic sphingomyelinases in tumor necrosis factor signaling. Cell 78: 1005-1015

Wolff RA, Dobrowsky RT, Bielawska A, Obeid LM and Hannun YA (1994) Role of ceramide-activated protein phosphatase in ceramide-mediated signal transduction. J. Biol. Chem. 269: 19605-19609

Wright SC, Kumar P, Tam AW, Shen N, Varma M and Larrick JW (1992) Apoptosis and DNA fragmentation precede TNF-induced cytolysis in U937 cells. J. Cell. Biochem. 48: 344-355

XiaZ. Dickens M, Raingeaud J, Davis RJ and Greenberg ME (1995) Opposing effects of ERK and JNK-p35 MAP kinases on apoptosis. Science 270: 1326-1331

Yeo B, Zhang Y, Delikat S, Mathias S, Basu S and Kolesnick R (1995) Phosphorylation of Raf by ceramide-activated protein kinase. Nature 378 : $307-310$

Zhang N, Alter N, Reed JC, Borner C, Obeid LM and Hannun YA (1996) Bcl-2 interrupts the ceramide-mediated pathway of cell death. Proc. Natl. Acad. Sci. USA 93: 5325-5328 